\title{
Pengaruh Variasi Massa Batang Pisang dan Cangkang Kelapa Sawit terhadap Sifat Fisis dan Mekanis Komposit Papan Partikel Menggunakan Perekat Resin Epoksi
}

\author{
Aminah Lestari*, Mora \\ Laboratorium Fisika Material, Jurusan Fisika \\ Fakultas Matematika dan Ilmu Pengetahuan Alam Universitas Andalas \\ Kampus UNAND Limau Manis, Padang, 25163, Indonesia \\ *aminah.lestari090696@gmail.com
}

\begin{abstract}
ABSTRAK
Telah dilakukan penelitian tentang pengaruh variasi massa batang pisang, cangkang kelapa sawit dan resin epoksi terhadap sifat fisis dan sifat mekanis komposit papan partikel. Penelitian ini menggunakan metode penggilingan ball mill untuk mendapakan ukuran partikel yang lolos ayakan 100 mesh. Hasil ayakan dibagi menjadi lima komposisi dengan rasio batang pisang terhadap cangkang kelapa sawit sebesar 80:0, 60:20, 40:40, 20:60, dan 0:80. Sifat fisis yang telah diuji terdiri dari kerapatan, kadar air, dan daya serap air sedangkan sifat mekanis meliputi kuat lentur dan kuat tekan. Sifat mekanis diuji menggunakan Universal Testing Machine (UTM). Hasil uji sifat fisis menunjukan bahwa kadar air dan daya serap air papan partikel memenuhi standar SNI 03-2105-2006, sedangkan kerapatan melewati batas atas yang diperbolehkan. Kuat tekan dan kuat tekan sejajar memenuhi standar SNI 03-2105-2006, sedangkan pada kuat lentur belum memenuhi. Variasi massa terbaik untuk pembuatan papan partikel adalah dengan menggunakan salah satu filler baik batang pisang ataupun cangkang kelapa sawit.

Kata kunci: komposit, papan partikel, cangkang kelapa sawit, batang pisang, ball mill
\end{abstract}

\section{ABSTRACT}

A study regarding the effects of mass variety of banana stem, palm oil shell and epoxy resin on physical and mechanical properties of composite particle board has been conducted. A ball mill grinding method was used in this study to obtain microparticles that pass a 100 mesh (149 micron) sieve. The produced filler microparticles were subsequently separated in to five compositions within specified volumetric percentage ratio (banana stem:palm oil shell) namely 80:0; 60:20; 40:40; 20:60 and 0:80. The measured physical properties were density, water content, and water absorption, while the mechanical properties were bending, compressive and internal bending strength using Universal Testing Machine (UTM). The physical properties of the composite fulfill the requirementof SNI 03-2105-2006 standard conforming to water content and water absorption, except density that is higher than allowed by the standard. Compressive and internal bending strength fulfill the requirement where as the bending strength does not fullfill. The best mass variation for creating a composite particle board is using one of two fillers either banana stem or palm oil shell.

Keywords:composites, particle board, palm oil shell, banana stem, ball mill

\section{PENDAHULUAN}

Kebutuhan akan papan yang diperoleh dari kayu-kayu hasil hutan saat ini mengalami peningkatan secara signifikan. Suyanti (2013) menyebutkan, kebutuhan perkayuan di Indonesia diperkirakan 70 juta $\mathrm{m}^{3}$ pertahun dengan kenaikan rata-rata sebesar $14,2 \%$ per tahun. Peningkatan kebutuhan papan ini mengakibatkan sumber daya hutan semakin hari semakin berkurang. Oleh karena itu, perlu dilakukan upaya dalam mengurangi ketergantungan terhadap hasil hutan seperti efisiensi pemanfaatan kayu atau mencari pengganti kayu.

Salah satu material yang banyak dikembangkan saat ini adalah material komposit seperti papan serat, papan laminat dan papan partikel yang merupakan paduan dari dua atau lebih material penyusun. Salah satu keuntungan dari material komposit ini yaitu dapat mengurangi eksploitasi kayu hasil hutan dan menggantinya dengan bahan-bahan alam lain seperti batang pisang, ampas tebu, sekam padi, dan cangkang kelapa sawit yang banyak tersedia (Smallman dan Bishop, 1999).

Papan partikel merupakan salah satu papan yang dihasilkan dari partikel-partikel kayu dan diikat menggunakan zat perekat. Secara umum, pembuatan papan partikel menggunakan bahan yang mengandung hemiselulosa, selulosa, dan lignin (Haygreen dan Bowyer, 1989). Bahan berlignoselulosa yang dapat dimodifikasi menjadi papan partikel salah satunya adalah 
pelepah pisang yang memiliki jaringan selular dengan pori-pori yang saling berhubungan sehingga berpotensi untuk dimanfaatkan sebagai material komposit (Indrawati, 2009). Selain itu, batang pisang dapat dikombinasikan dengan bahan alam lain seperti bubuk kayu atau cangkang kelapa sawit untuk menambah kekuatan dari suatu material (Endriatno, 2015).

Penelitian mengenai papan partikel telah dilakukan oleh Cahyana (2013) menggunakan limbah serutan rotan dan cangkang kelapa sawit dengan perekat urea formaldehida. Dari penelitian ini didapatkanbahwa semakin banyak serutan rotan dan konsentrasi perekat semakin baik pula mutu papan partikel, namun kuat lentur yang didapat $697 \mathrm{~kg} / \mathrm{cm}^{2}$ masih belum memenuhi standar SNI 03-2105-2006.

Malau dkk. (2015) juga melakukan penelitian tentang kualitas papan partikel batang pisang barangan berdasarkan variasi kadar perekat phenol formaldehida.Hasil penelitian ini menunjukkanbahwa variasi perekat terbaik adalah $16 \%$ karena terjadi penyebaran filler yang lebih merata dibandingkan dengan variasi $8 \%, 10 \%, 12 \%, 14 \%$. Kuat lentur yang didapat 27,6 $\mathrm{kg} / \mathrm{cm}^{2}$ dan kuat tekan $70,7 \mathrm{~kg} / \mathrm{cm}^{2}$ masih belum memenuhi standar SNI 03-2150-2006 sehingga perlu dilakukan penelitian lanjut dengan meningkatkan kadar perekat yang digunakan agar sifat mekanik papan semakin meningkat.

Sifat fisis dan mekanik dari papan partikel masih memiliki kualitas yang rendah, hal ini disebabkan karena ukuran partikel yang masih besar (Iswanto, 2009), campuran pengisi sebagai penguat tambahan, dan kadar perekat yang digunakan. Berdasarkan uraian di atas maka perlu dilakukan penelitian mengenai papan partikel dari batang pisang dan cangkang kelapa sawit (partikel lolos ayakan 100 mesh) menggunakan polimer berbasis resin epoksi yang merupakan kelompok perekat thermosetting.

\section{METODE}

Bahan yang digunakan dalam penelitian ini adalah batang pisang, cangkang kelapa sawit dan resin epoksi. Batang pisang dan cangkang kelapa sawit yang sudah dibersihkan dan dikeringkan, dipotong kecil-kecil untuk mempermudah proses penggilingan. Partikel dibuat menggunakan metode penggilingan ball mill yang menggunakan bola-bola penghancur dalam sebuah tabung horizontal yang berputar. Bahan yang sudah digiling kemudian diayak menggunakan ayakan 100 mesh dan hasil ayakan akan digunakan sebagai pengisi papan partikel.

Partikel yang diperoleh dicampur dalam wadah sesuai dengan komposisi masingmasing sampel dengan massa total yaitu 90 g (larutan epoksi $20 \%$ dan katalis 1\% dari massa perekat epoksi) yang diaduk menggunakan mixer sampai homogen, kemudian sampel dituangkan dalam cetakan yang sudah dilapisi aluminium foil. Permukaan sampel diratakan dengan penutup yang tersedia pada cetakan dan ditekan menggunakan hot packing press dengan pembebanan 2 ton pada suhu $150{ }^{\circ} \mathrm{C}$ selama 10 menit. Sampel dikeringkan selama 24 jam dan kemudian dilakukan uji sifat fisis dan uji mekanik.

Hasil pengujian sifat fisis dan mekanik papan partikel dibandingkan dengan standar SNI 03-2105-2006. Parameter uji sifat fisis yang akan dilakukan adalah kerapatan, kadar air, dan daya serap air. Sedangkan sifat mekanik yang diuji meliputi kuat lentur (MOE), kuat tekan (MOR), dan kuat tekan sejajar.

\section{HASIL DAN DISKUSI}

\subsection{Uji Sifat Fisis}

\subsubsection{Kerapatan}

Kerapatan papan partikel yang didapatkan menurun menuju nilai yang ditetapkan SNI 03-2105-2006 $\left(0,5 \mathrm{~g} / \mathrm{cm}^{3}-0,9 \mathrm{~g} / \mathrm{cm}^{3}\right)$ ketika persentase massa batang pisang semakin berkurang. Kerapatan papan pada persentase 80:0 dan 0:80 sama besar. Hal ini disebabkan papan pada persentase 0:80 lebih tipis dibandingkan pada persentase lain yang mengakibatkan volume papan lebih kecil sehingga kerapatan papan yang didapat lebih besar. Muharam (1995) menyatakan bahwa faktor penting yang mempengaruhi densitas papan partikel adalah kerapatan bahan baku dan banyaknya bahan pada lembaran (kepadatan lembaran). 
Standar SNI 03-2105-2006 menetapkan kerapatan papan partikel yaitu 0,5 g/cm $-0,9$ $\mathrm{g} / \mathrm{cm}^{3}$, maka kerapatan papan partikel yang didapatkan melebihi standar yang ditetapkan. Berdasarkan nilai kerapatan yang didapat menunjukkan kerapatan papan diatas $0,9 \mathrm{~g} / \mathrm{cm}^{3}$ yang dapat dikategorikan kedalam papan partikel berkerapatan tinggi (high density board) dimana nilai kerapatan papan lebih dari $0,8 \mathrm{~g} / \mathrm{cm}^{3}$ (Maloney, 1997). Hasil pengukuran kerapatan papan partikel dapat dilihat pada Gambar 1.

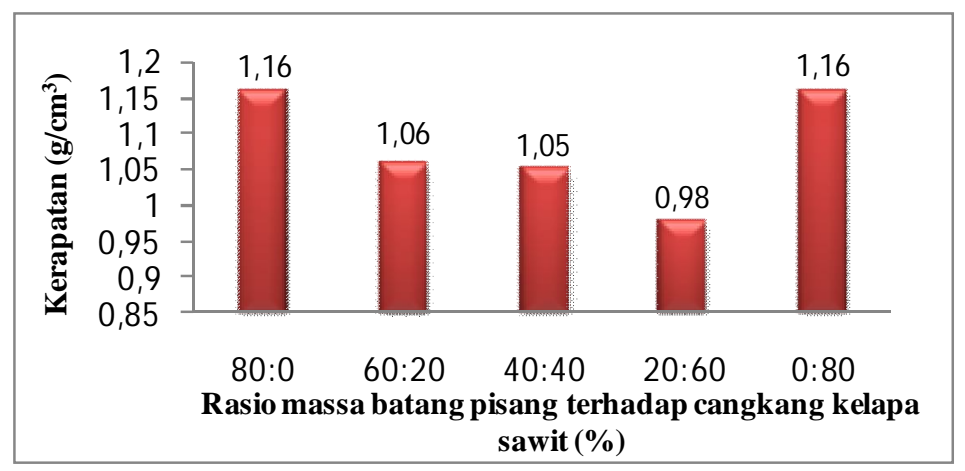

Gambar 2 Pengaruh Variasi Massa Batang Pisang dan Cangkang Kelapa Sawit terhadap Kerapatan Papan Partikel

\subsubsection{Kadar Air}

Kadar air papan partikel meningkat seiring berkurangnya persentase massa batang pisang. Kadar air yang didapat pada komposisi 80:0 dan 0:80 juga hampir sama. Hal ini disebabkan oleh kadar air bahan yang digunakan. Semakin tinggi kadar air bahan, maka semakin tinggi kadar air papan yang dihasilkan. Kadar air dipengaruhi oleh kandungan lignin yang bersifat menolak air sedangkan kandungan selulosa, hemiselulosa, dan karbohidrat yang cenderung menyerap air (Iswanto, 2008). Kandungan lignin batang pisang lebih tinggi $(33,51 \%)$ dibandingkan kandungan lignin cangkang kelapa sawit (2,94\%). Kandungan hemiselulosa cangkang kelapa sawit lebih tinggi (27,7\%) dibandingkan kandungan hemiselulosa batang pisang (20\%), sehingga pada komposisi tidak ada penyampuran filler yaitu komposisi 80:0 dan 0:80 kadar air papan hampir sama. Hasil pengukuran kadar air papan partikel dapat dilihat pada Gambar 2.

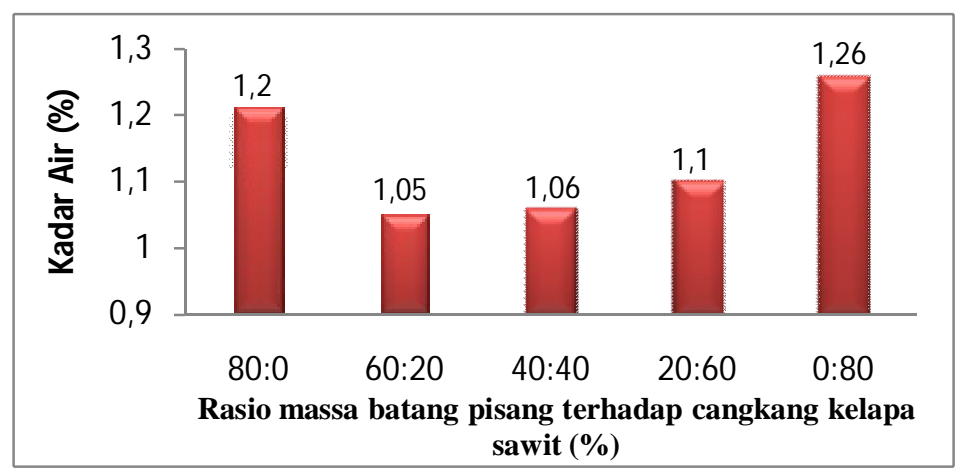

Gambar 3 Pengaruh Variasi Massa Batang Pisang dan Cangkang Kelapa Sawit terhadap Kadar Air Papan Partikel

Berdasarkan standar SNI 03-2105-2006 kadar air papan partikel yang ditetapkan tidak melebihi $14 \%$. Dengan demikian kadar air semua komposisi papan partikel yang didapatkan pada penelitian ini memenuhi standar.

\subsubsection{Daya Serap Air}

Daya serap air papan partikel semakin menurun ketika persentase batang pisang semakin berkurang. Papan partikel dengan bahan dari batang pisang bersifat higroskopis sehingga mudah menyerap air yang menyebabkan daya serap air semakin tinggi (Malau, 2015). 
Penambahan cangkang sawit yang memiliki sifat sukar menyerap air yang menyebabkan daya serap air semakin menurun (Cahyana, 2013). Hasil pengukuran daya serap air papan partikel dapat dilihat pada Gambar 3.

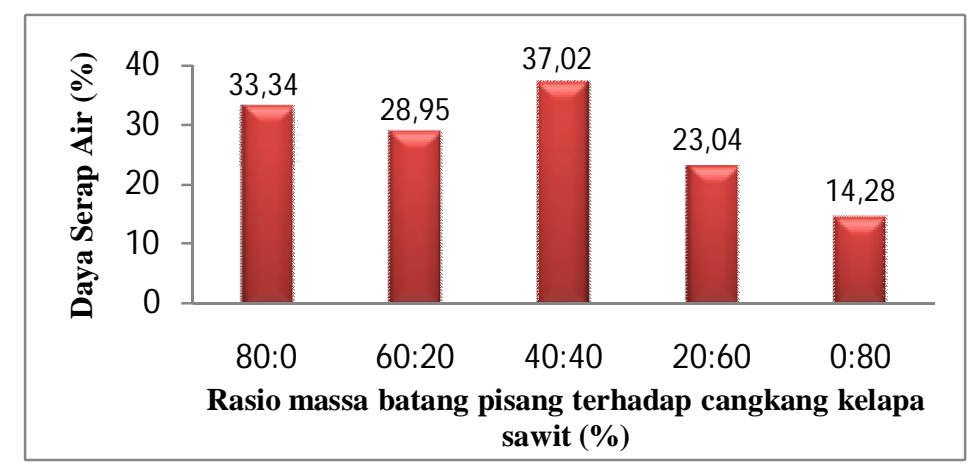

Gambar 4 Pengaruh Variasi Massa Batang Pisang dan Cangkang Kelapa Sawit terhadap Daya serap Air Papan Partikel

Pada persentase 40:40 daya serap air kembali meningkat. Hal ini disebabkan adanya peristiwa spring back yaitu usaha untuk pembebasan dari tekanan yang diberikan pada waktu proses pengempaan yang lebih tinggi dibandingkan komposisi lain sehingga ketebalan dari papan bertambah dan rongga pada papan juga semakin besar yang menyebabkan kemampuan papan menyerap air semakin tinggi (Malau, 2015). Bahan yang berasal dari jenis monokotil mempunyai jaringan parenkim diantara bundel-bundel seratnya yang awalnya mengandung air, tetapi setelah ada proses pengeringan jaringan ini akan membentuk pori-pori yang cenderung menyerap cairan polar seperti air (Zukarnain, 2000).

Standar SNI 03-2105-2006 tidak mensyaratkan nilai daya serap air dan karena itu dianjurkan standar JIS 2003 yang menetapkan nilai daya serap air yaitu 4-40\%. Berdasarkan standar JIS nilai daya serap air yang didapatkan pada papan partikel semua variasi massa memenuhi nilai yang ditetapkan.

\subsection{Sifat Mekanis}

\subsubsection{Kuat Lentur (MOE)}

Kuat lentur papan menurun seiring dengan pertambahan persentase massa dari partikel cangkang kelapa sawit. Kuat lentur papan yang semakin menurun dipengaruhi oleh modulus elastisitas bahan yang digunakan. Modulus elastisitas batang pisang lebih tinggi (7,7-20 MPa) dibandingakan modulus elastisitas cangkang kelapa sawit (3-4 MPa). Sehingga penambahan cangkang kelapa sawit menyebabkan kuat lentur papan semakin menurun.

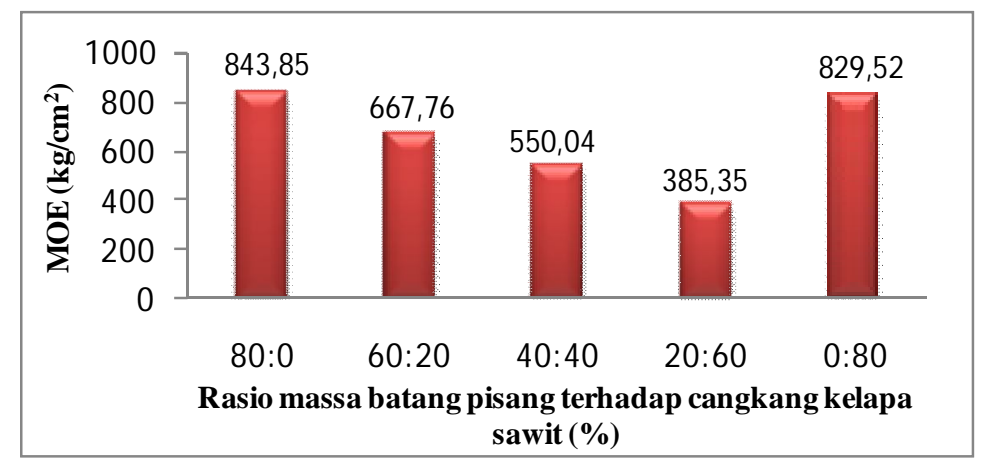

Gambar 5 Pengaruh Variasi Massa Batang pisang dan Cangkang kelapa Sawit terhadap Kuat Lentur (MOE) Papan Partikel

Komposisi papan persentase 80:0 dan 0:80 kuat lentur papan hampir sama, hal ini diakibatkan karena adanya gaya adeshi yaitu gaya tarik menarik antara dua molekul yang berbeda (batang pisang dengan perekat atau cangkang kelapa sawit dengan perekat) yang 
mengakibatkan ikatan antara molekul semakin kuat, sehingga kekuatan lentur papan juga semakin meningkat. Hasil pengukuran kuat lentur papan partikel dapat dilihat pada Gambar 4.

Standar SNI 03-2105-2006 kuat lentur (MOE) papan partikel yang ditetapkan minimal $20.400 \mathrm{~kg} / \mathrm{cm}^{2}$. Dengan demikian nilai kuat lentur papan partikel yang didapatkan pada penelitian ini belum memenuhi standar papan partikel yang disyaratkan tetapi hasil yang didapatkan sudah melebihi kuat lentur yang didapatkan pada penelitian Cahyana (2013) dan Malau (2015).

\subsubsection{Kuat Tekan (MOR)}

Kuat tekan papan menurun dengan pertambahan massa dari partikel cangkang kelapa sawit. Haygreen dan Bowyer (1996) menyatakan nilai kuat tekan papan partikel berbanding lurus dengan nilai kerapatan papan yang dihasilkan artinya semakin tinggi kerapatan maka semakin tinggi nilai kuat tekan papan partikel. Komposisi 0:80 kuat tekan papan yang didapatkan meningkat kembali disebabkan karena terjadi interface akibat dari besarnya gaya adeshi pada komposisi 80:0 dan 0:80 sehingga ikatan antara permukaannya semakin kuat (Endriatno, 2015). Hasil pengukuran kuat tekan papan partikel dapat dilihat pada Gambar 5.

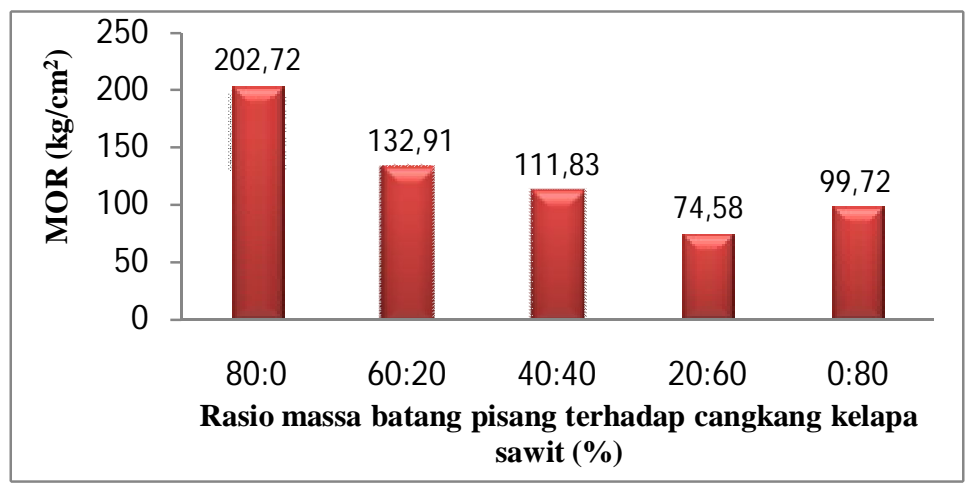

Gambar 6 Pengaruh Variasi Massa Batang Pisang dan Cangkang kelapa Sawit terhadap Kuat Tekan (MOR) Papan Partikel

Standar SNI 03-2105-2006 nilai kuat tekan (MOR) papan partikel yang ditetapkan minimal $82 \mathrm{~kg} / \mathrm{cm}^{2}$. Dengan demikian nilai kuat tekan papan partikel yang didapatkan pada penelitian ini untuk tiap komposisi partikel batang pisang yang tinggi memenuhi standar papan partikel sedangkan untuk komposisi partikel 20:60 belum memenuhi standar yang ditetapkan.

\subsubsection{Kuat Tekan Sejajar}

Kuat tekan sejajar papan semakin meningkat jika persentase partikel cangkang kelapa sawit yang digunakan semakin tinggi. Cangkang kelapa sawit memiliki kekerasan yang lebih tinggi (2000 MPa) dibandingkan batang pisang (816 MPa) (Iswanto, 2009). Hasil pengukuran kuat tekan sejajar papan partikel dapat dilihat pada Gambar 6.

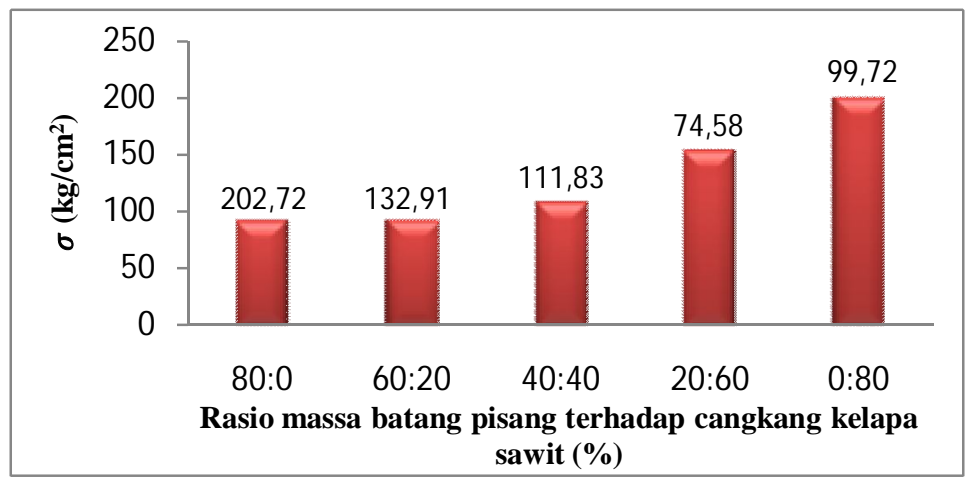

Gambar 7 Pengaruh Variasi Massa Batang Pisang dan Cangkang kelapa Sawit terhadap Kuat Tekan Sejajar Papan Partikel 
Berdasarkan standar SNI 03-2105-2006 kuat tekan sejajar papan partikel yang ditetapkan minimal $15 \mathrm{~kg} / \mathrm{cm}^{2}$. Dengan demikian kuat tekan sejajar papan partikel yang didapatkan pada penelitian ini untuk semua variasi memenuhi standar papan partikel yang ditetapkan.

\section{KESIMPULAN}

Berdasarkan hasil penelitian yang telah didapatkan, dapat diambil kesimpulan bahwa uji sifat fisis komposit papan partikel mempunyai nilai daya serap air dan kadar air memenuhi standar SNI 03-2105-2006, namun memiliki nilai kerapatan yang melewati standar SNI 032105-2006. Sementara berdasarkan uji sifat mekanik komposit papan partikel mempunyai nilai kuat tekan (MOR) dan kuat tekan sejajar yang memenuhi standar SNI 03-2105-2006, namun memiliki nilai kuat lentur (MOE) yang tidak memenuhi standar SNI 03-2105-2006.

Variasi massa yang terbaik dalam pembuatan papan partikel yaitu dengan menggunakan salah satu filler baik batang pisang (kerapatan, kadar air, kuat lentur, dan kuat tekan) ataupun cangkang kelapa sawit (daya serap air dan kuat tekan sejajar) yang didapatkan dapat diaplikasikan berdasarkan dari hasil uji sifat mekanik dan uji sifat fisis digunakan untuk bahan pembuatan pintu, meja, pelapis dinding, lemari dan pelindung komponen elektronik seperti kotak speaker.

\section{DAFTAR PUSTAKA}

Cahyana, B. T., "Papan Partikel dari Limbah Serutan Rotan dan Cangkang Kelapa Sawit", (Jurnal Riset Industri Hasil Hutan, 2013), hal. 17-23.

Endriatno, N. A., "Analisis Sifat Mekanik Komposit Sandwich Serat Pelepah Pisang dengan Core Kayu Biti”, (Jurnal Ilmiah Teknik Mesin, 2015), hal. 1-8.

Haygreen, J. G. dan Bowyer, J. L.,Hutan dan Ilmu Kayu Suatu Pengantar (Universitas Gadjah Mada, Yogyakarta, 1989), hal. 230-235.

Indrawati, E., "Koefisien Absorpsi Bunyi Bahan Akustik dari Pelepah Pisang dengan Kerapatan yang Berbeda", (Jurnal Neutrino, 2009), hal. 31-33.

Iswanto, A. H, "Papan Partikel dari Ampas Tebu", Skripsi S1, Universitas Sumatera Utara, 2009.

Malau, J. C., Sucipto, T. dan Iswanto, A. H., "Kualitas Papan Partikel Batang Pisang Barangan Berdasarkan Variasi Kadar Perekat Phenol Formaldehida", (Jurnal Kehutanan, 2015), hal. 4-7.

Maloney, T. M., Modern Particle board and Dry Proces Fiber board Manufacturing (Miller Freman Inc, San Fransisco, 1997), hal. 198-216.

Muharam, A, "Pengaruh Ukuran Partikel dan Kerapatan Lembaran terhadap Sifat Fisis dan Mekanis Papan Partikel Ampas Tebu", Skripsi S1, Institut Pertanian Bogor, 1995.

Sallman, R. E. dan Bishop, R. J., "Metalurgi Fisik Modern dan Rekayasa Material (Jakarta, Erlangga, 1999), hal. 26-32.

Suyanti dan Supriyadi, A., "Budidaya dan Pengelolaan Hasil Hutan Edisi revisi (Jakarta, Penebar Swadaya, 2008), hal. 35-42.

Zukarnain, "Impregnasi Resin Pinus Merkusi dan Asam Akrilat kedalam Kayu Kelapa Sawit Menggunakan Berbgai Pelarut", Tesis S2, Universitas Sumatera Utara, 2000. 